\title{
Development of Materials Learning Based on ICT and Scientific Approach 5th Grade of Elementary School
}

\author{
Ravita Deasy Rahmawati ${ }^{1}$, Wiwi Isnaeni ${ }^{2}$, Yuli Utanto ${ }^{3}$ \\ \{ravita.deasy@yahoo.com ${ }^{1}$, wiwiisna@mail.unnes.ac.id ${ }^{2}, \underline{\left.\text { utanto1979@mail.unnes.ac.id }{ }^{3}\right\}}$ \\ Universitas Negeri Semarang ${ }^{1}$, Universitas Negeri Semarang ${ }^{2}$, Universitas Negeri Semarang ${ }^{3}$
}

\begin{abstract}
The purpose of this study developed a thematic materials learning based on ICT and scientific approach to increase literation ICT of student. This research and development model used research and development (R\&D) with model 4D. The development of teaching materials began with determining the characteristics of teaching materials, namely teaching materials that use the web (ICT-based) and scientific approach. Materials learning contained materials, learning activities with scientific approach, pictures, videos to support learning, and learning questions. Validity average by ICT expert gave the results $73,3 \%$, which meant that the content section was too long and needed to be improved. After being revised teaching materials are declared good and feasible to use. The results of the feasibility of teaching materials was $83.3 \%$ (very good). The results of the feasibility test from the experts of the learning process $90 \%$ (very good). Based on these results, ICT-based teaching materials and scientific approach at theme of Environment is Our Friend deserve to be used as teaching material containing elements that facilitate $5^{\text {th }}$ students of elementary school to conduct learning activities using the scientific approach.
\end{abstract}

Keywords: materials learning, ICT, scientific approach, development

\section{Introduction}

The 2013 curriculum aims to prepare Indonesian people who have the ability to live as individuals and citizens who are productive, creative, innovative, and effective, and able to contribute to the life of the world, nation, state and civilization of the world. The 2013 curriculum is a strategic step in facing globalization and the demands of the Indonesian people in the future. Later, 21st century learning will require high-level thinking skills and technology-based by mastering 21 st century skills which include 1) life and career skills, 2) learning and innovation skills, and 3) information, media, and technology skills [1]. This 21st century learning requires students to master competencies including critical thinking, problem solving, communication, collaboration, creativity, and digital literacy [2]. To create competencies that must be possessed in the 21 st century, learning activities must be designed to develop high-level thinking competencies of students or known as HOTS (high order thinking skills). These competencies are not taught separately, but are integrated in learning.

As explained in Permendikbud No. 22 Chapter 2 years 2016 concerning process standards, it was stated that the approach used in learning is the scientific approach. In the scientific approach, activities include observing, asking, trying, reasoning, and communicating [3]. Scientific approach familiarizes students with independent learning and optimizing their intelligence [4]. Scientific approach is closely related to Constructivism Theory by Vygotsky 
who argues that meaningful learning is if in learning, students actively construct knowledge and create meaning as a result of thinking and interaction between the physical and social environment [5]. In this scientific approach students are expected not only to memorize it, but can obtain a concept that is intact through this experience. This is in accordance with the competencies that must be possessed in the 21st century. Based on P21 [1], one of the competencies students must possess is ICT literacy.

To be able to carry out this learning, the teacher must design learning that can make students become active, innovative, creative, and fun. One of them is by holding learning activities that can stimulate students' minds to think higher. Learning activities can also be supported by the presence of teaching materials. Teaching materials as all forms of material used to help teachers / instructors in carrying out teaching and learning activities [6]. Learning activities would be active, interesting, and meaningful if using teaching materials. In learning activities teaching materials are very important for teachers and students [7]. This teaching material will be compiled in a web that can be accessed via mobile phones / computers connected to the internet. This ICT-based teaching material is expected to be an alternative choice for teachers and facilitate students to develop their ICT competencies

Previous research entitled Teaching and Learning with Technology: The effectiveness of ICT Integration in Schools results showed that ICT integration has great effectiveness for teachers and students. The findings show that teacher preparation equipped with ICT tools and facilities is one of the main factors in the success of technology-based teaching and learning [8]. This article entitled The Role and Impact of ICT in Improving The Quality of Education: An Overview highlights the impact and benefits of ICT in education, its limitations and challenges to the education system. Conclusion of this article is that information communication technology affects all aspects of life, where the impact of ICT is very significant is education. ICT help expand access to education, motivate learning, facilitate the acquisition of basic skills, and can change the learning environment so as to help improve the quality of education. ICT has tremendous potential for education. ICT enables a teacher to reach widely in an efficient and effective manner. This helps teachers and institutions to become more modern and dynamic. Finally, the use of ICTs will enhance students' learning experiences [9]. In the other case, a research did by shows that there are differences in values between students' vocabulary mastery using ICT-based learning and not [10]. In Trinidad and Tobago, already use PowerPoint, animation and practical activities and virtual laboratories in learning [11]. Ikan, Tikochinski, and Bashan created CLI-O to be used and related to theories that enable teachers, teacher educators, and researchers to apply ICT in teaching as a process of building new pedagogies that are adapted to 21st century needs [12]. Nawi, Yusoff, Abbas, and Ajmain suggested in their research that teachers must be innovative and creative in diversifying their teaching methods, including the use of websites to make T\&L more attractive and thus improve their professional skills [13].

\section{Method}

This research is development research whose products are ICT-based teaching materials with a scientific approach to the theme of our Friends Environment. The development model used is 4D (devine, design, develop, and cemented) [14]. However, researchers only use stages to $3 \mathrm{D}$, so the dissemination stage is not done due to time constraints. 
At the define stage, researchers conduct: a) basic competency analysis, b) material analysis, and c) analysis of Theme 8 Student Books "Environment is Our Friend". At the design stage, the researcher conducts: a) program selection, which is the right program used for ICT-based learning facilities and b) material writing, activity, and learning evaluation. While in the development stage the researcher conducts product validation by expert judgment followed by product revisions.

In this development, researchers developed ICT-based teaching materials using web media. This teaching material can be accessed using mobile phones and computers connected to the internet. The material in teaching materials is presented using a scientific approach accompanied by illustrations, learning videos, student activities, and evaluations.

Products that have been developed will be tested for their feasibility. The instrument used is an ICT-based teaching material validation sheet. The feasibility test was conducted aimed at assessing teaching materials that have been developed with the competencies to be achieved in learning. The feasibility test uses a validation sheet and is conducted by two Basic Education lecturers and one vocational teacher in Computer and Network Engineering.

The data analysis technique used by the researcher is quantitative descriptive analysis with the percentage obtained based on the score. From the results of evaluations from experts, it will be analyzed in the following ways:

$$
\begin{aligned}
& P=\frac{F}{N} \times 100 \% \\
& \text { Explanation: } \\
& \mathrm{P} \quad: \text { percentage } \\
& \mathrm{F} \quad \text { : obtained value } \\
& \mathrm{N} \quad \text { : overall value }
\end{aligned}
$$

Once calculated, the percentage is interpreted to determine the value of the feasibility of teaching materials using the table below.

Table 1. Teaching Material Assessment Criteria

\begin{tabular}{cl}
\hline Percentage & \multicolumn{1}{c}{ Criteria Interpretation } \\
\hline $0 \%-25 \%$ & $\begin{array}{l}\text { Very good, so it can be used without } \\
\text { revision. }\end{array}$ \\
$26 \%-50 \%$ & $\begin{array}{l}\text { Good, so it can be used with revisions. } \\
\text { Enough, so that it can be used with } \\
\text { revisions and reviews again. } \\
\text { Less, so it can't be used. }\end{array}$ \\
\hline
\end{tabular}

\section{Result and Discussion}

\subsection{Result}

The results of product development from this study are ICT-based teaching materials that can be accessed through the website http://zimpel.000webhostapp.com com using mobile/ computer connected to the internet. This teaching material contains basic competencies, observing, asking, discussing, trying, and concluding activities. The learning material is equipped with learning videos and pictures / illustrations to make it easier for students to 
understand material. Learning activities are also accompanied by practicum. This teaching material also presents learning evaluations, which are found in the "questions" menu.

The feasibility analysis of teaching materials in the form of this web researchers refer to BSNP (2006) which includes: 1) content feasibility, 2) language feasibility, 3) feasibility of presentation, and 4) graphic feasibility [15]. The following are the results of validation tests by experts.

Table 2. Frequency Distribution of Material Expert

\begin{tabular}{|c|c|c|}
\hline \multirow[t]{2}{*}{ Criteria } & \multicolumn{2}{|c|}{ Cheklist } \\
\hline & Yes & No \\
\hline $\begin{array}{l}\text { Conformity with curriculum } \\
2013\end{array}$ & 3 & 0 \\
\hline $\begin{array}{l}\text { Accuracy of the use of } \\
\text { sentences }\end{array}$ & 2 & 1 \\
\hline Encourage student curiosity & 2 & 1 \\
\hline ITC literation & 3 & 0 \\
\hline Total & 10 & 2 \\
\hline Percentage & $83 \%$ & $17 \%$ \\
\hline
\end{tabular}

Table 3. Frequency Distribution of Learning Expert

\begin{tabular}{lccc}
\hline & Criteria & \multicolumn{2}{c}{ Yheklist } \\
\cline { 3 - 4 } & & 3 & No \\
\hline $\begin{array}{l}\text { Conformity } \\
2013\end{array}$ & with curriculum & 0 \\
$\begin{array}{l}\text { Accuracy of the use of } \\
\text { sentences }\end{array}$ & 2 & 1 \\
$\begin{array}{l}\text { Encourage student curiosity } \\
\text { Elements of the scientific } \\
\text { approach }\end{array}$ & 3 & 0 \\
\hline \multicolumn{2}{c}{ Total } & 3 & 0 \\
\hline \multicolumn{2}{c}{ Percentage } & 11 & 1 \\
\hline
\end{tabular}

Table 4. Frequency Distribution of ICT Expert

\begin{tabular}{lcc}
\hline \multicolumn{1}{c}{ Criteria } & \multicolumn{2}{c}{ Cheklist } \\
\cline { 2 - 3 } & Yes & No \\
\hline $\begin{array}{l}\text { Accuracy of display in teaching } \\
\text { material program }\end{array}$ & 3 & 0 \\
$\begin{array}{l}\text { Accuracy of features in } \\
\text { teaching material }\end{array}$ & 3 & 0 \\
$\begin{array}{l}\text { Readability of text teaching } \\
\text { material program }\end{array}$ & 2 & 1 \\
$\begin{array}{l}\text { Easy of operation in teaching } \\
\text { material program } \\
\begin{array}{l}\text { Convenience in teaching } \\
\text { material program }\end{array}\end{array}$ & 1 & 2 \\
\hline \multicolumn{1}{c}{ Total } & 2 & 1 \\
\hline \multicolumn{1}{c}{ Percentage } & 11 & 4 \\
\hline
\end{tabular}


Based on result of material expert judgement, materials learning was $83.3 \%$ (very good). Based on result of learning expert judgement, material learning was $91,7 \%$ (very good). Based on result of material expert judgement, materials learning which meant that the content section was too long and needed to be improved. After being revised by making content on a shorter menu, materials learning declared good and feasible to use. Revisions made by researchers based on suggestions from the experts are as follows.

a) improve writing color to be easy to read
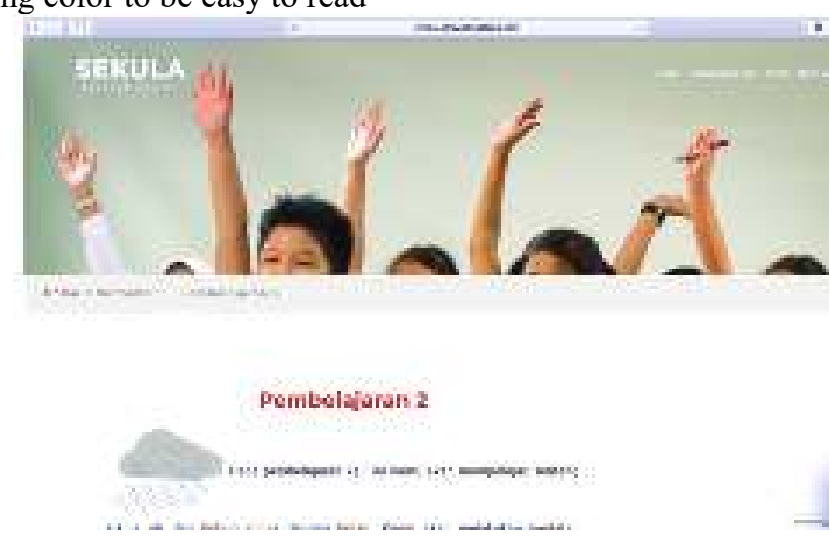

Fig. 1. Font at Teaching Material

b) make content shorter

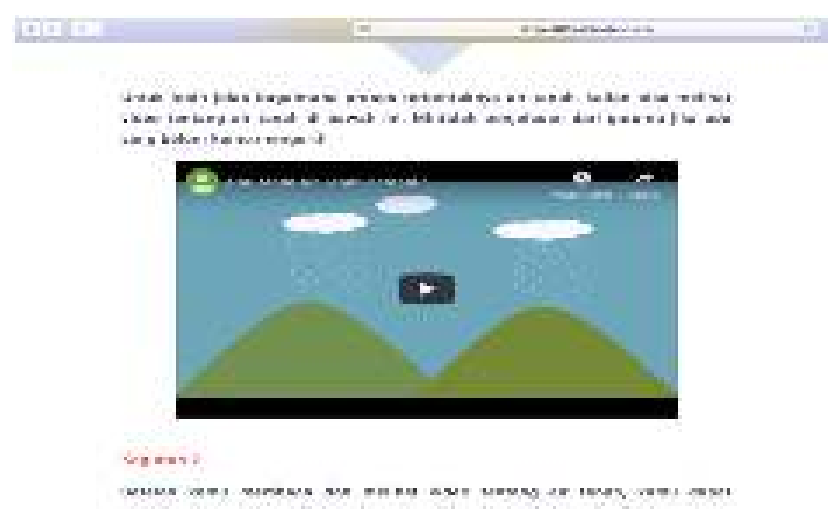

Fig. 1. Content at Teaching Material

\subsection{Discusson}

Based on the results described above, teaching materials developed in accordance with learning with a scientific approach which can facilitate students to have ICT literacy competencies. ICT literacy competencies are: 1) connecting digital devices to the internet, 2) using digital devices to study, and 3) using digital devices according to the rules [16]. This is consistent with the research conducted by Bindu with results the active and collaborative 
learning conditions facilitated by ICT help develop a knowledge-based student community in the 21 st century [17]. In addition, Nwigbo and Madhu say that the focus on the use of ICT in schools by students and teachers can support the learning and teaching process [18]. This is in accordance with the results of this study

\section{Conclusion}

Based on the discussion above, it can be concluded that: 1) teaching materials that have been developed have met general requirements such as basic competencies, student activities, and evaluation and 2) the instructional materials developed have fulfilled the eligible criteria so that the teaching materials developed are appropriate to be used as alternative thematic teaching materials on the theme of grade 5 in elementary school 


\section{References}

[1] Partnership for 21st Century Skills. (n.d.). Learning for 21st Skills. Maret 10, 2019. http://www.battelleforkids.org/networks/p21

[2] McNicol, S. \& Lewin, C. (2015, October 27). Supporting the Development of 21st Century Skills through ICT. Universität Potsdam, 2015 (07), pp. 181-198. December 8, 2018. https://publishup.unipotsdam.de/opus4-ubp/frontdoor/index/index/docId/8267

[3] Kementrian Pendidikan dan Kebudayaan Republik Indonesia. 2016. Peraturan Menteri Pendidikan dan Kebudayaan tentang Standar Proses Pendidikan Dasar dan Menengah (Permendikbud No.22 Tahun 2016). Jakarta, DKI; Anies Baswedan. https://bsnp-indonesia.org/wpcontent/uploads/2009/06/Permendikbud_Tahun2016_Nomor022_Lampiran.pdf.

[4] Musfiqon \& Nurdyansyah. 2015. Pendekatan Pembelajaran Saintifik. Sidoarjo: Nizamia Learning Center.

[5] Daryanto \& Karim, S. (2017). Pembelajaran Abad 21 . Yogyakarta: Penerbit Gaya Media.

[6] Majid, A. 2011. Perencanaan Pembelajaran. Bandung: Rosdakarya.

[7] Ulfah, A., Bintari, H. S., \& Pamelasari, D. S. 2013. Pengembangan LKS IPA Berbasis Word Square Model Keterpaduan Connected. Unnes Science Education Journal, 2(2): pp. 239-44.

[8] Ghavifekr, S., Kunjappan, T., Ramasamy, L., \& Anthony, A. (2016). Teaching and Learning with ICT Tools: Issues and Challenges from Teachers' Perceptions. Malaysian Online Journal of Educational Technology. 4(2), 38-57.

[9] Saxena, N. (2017). The Role and Impact of ICT in Improving The Quality of Education: An Overview. International Journal of Engineering Sciences \& Research Technology:

doi: 10.5281 /zenodo.439205

[10] Hussain, Zakir. (2018). The Effect of ICT-Based Learning on Students'Vocabulary Mastery in Junior High School in Bandung. International Journal of Education. 10(2), 149-156.

[11] Sharma, M. R., Sharma, Aarti, and Sharma, Aditi. (2017). Using ICT-based Instructional Technologies to Teach Science: Perspectives from Teachers in Trinidad and Tobago. Australian Journal of Teacher Education. 42(10), 23-35

[12] Ikan, M.E., Tikochinski, B.T., and Bashan, Zipi. 2013. . Does Use of ICT-Based Teaching Encourage Innovative Interactions in the Classroom? Presentation of the CLI-O: Class Learning Interactions - Observation Tool. 9, 219-232.

[13] Nawi, A., Yusoff, M.F.A, Abbas, G.R.M., and Ajmain, H.H. 2014. Engaging Student Through ICT: Strategies and Challenges for Using Website in Teaching and Learning. International Journal on New Trends in Education and Their Implications. 5(3), 90-97.

[14] Fadilah, E.R., Suratno, \& Wahyuni, Dwi. 2015. Pengembangan Bahan Ajar Sistem Gerak Manusia Berbasis Peta Konsep dalam Meningkatkan Penguasaan Konsep Siswa Kelas XI SMA di Kabupaten Jember. Pancaran: 4(3), 41-50.

[15] Badan Standar Nasional Pendidikan. 2016. Naskah Akademik Instrumen Penilaian Buku Teks Pelajaran Pendidikan Dasar dan Menengah. Jakarta, DKI. http://bsnpindonesia.org/2016/04/01/pengumuman-penilaian-buku-teks-pelajaran-tahun-2016-2/

[16] Phuapan, P., Viriyavejakul C. \& Pimdee, P. 2015. An Analysis of Digital Literacy Skills among Thai University Seniors. Asian International Journal of Social Sciences, 15(4): 88 - 99.

[17] Bindu, C., N. 2016. Impact of ICT on Teaching and Learning: A Literature Review. International Journal of Management and Commerce Innovations. 4(1), 24-33.

[18] Nwigbo, S. \& Madhu, K. B. 2016. Impact of ICT on the Teaching and Learning Process. IOSR Journal of Mobile Computing \& Application. 3(2), 1-7. 